\title{
Variability of stone pine (Pinus pinea L.) fruit traits impacting pine nut yield
}

\author{
Verónica Loewe-Muñoz ${ }^{1} \cdot$ Mónica Balzarini $^{2} \cdot$ Claudia Delard $^{1} \cdot$ Andrea Álvarez $^{1}$
}

Received: 13 September 2018 / Accepted: 4 March 2019 / Published online: 10 April 2019

(C) INRA and Springer-Verlag France SAS, part of Springer Nature 2019

\begin{abstract}
- Key message Cone to pine nut yield (PY), an important commercial feature of stone pine cropping, was higher in Chile than in main producer countries. PY is highly variable along years and depends on pine nut number inside cones, followed by pine nut weight. Cone morphometry is not a good indicator of PY, thus selecting cones for size/weight will not improve it.

- Context Stone pine nuts are highly appreciated; however, pine nut yield (total pine nut weight as percentage of cone weight), important feature for the species cultivation, is variable and decreasing worldwide.

- Aims Evaluating inter-annual and spatial variability of fruit traits impacting pine nut yield.

- Methods Across years and plantation variability of fruit features were estimated from a multi-environment study monitored during 6 years in Chile. Variance component restricted maximum likelihood estimates were calculated for 14 fruit traits. Classification and Regression Tree (CART) was used to identify the variable best explaining pine nut yield.

- Results Pine nut yield (3.6-5\%) was higher than in main producer countries. Cone weight (521 g), length and diameter were correlated to most of seed and pine nut traits, but not to pine nut yield. The most important fruit trait in determining pine nut yield was pine nut number per cone, followed by pine nut weight. Pine nut yield showed high inter-annual and within plantation variability, whereas pine nut weight more spatial than temporal variability. Pine nut yield was superior in cones containing over 78 pine nuts.

- Conclusion Pine nut yield has high inter-annual variability, with cone morphometry not being a good indicator, thus selecting cones for size/weight will not improve cone to pine nut yield.
\end{abstract}

Keywords Kernel yield $\cdot$ Cone weight $\cdot$ Inter-annual variability $\cdot$ Between plantations variability $\cdot$ Stone pine $\cdot$ Leptoglossus occidentalis Heidemann · Pine nuts

\section{Handling Editor: Barry Alan Gardiner}

Contribution of co-authors VL designed the study, directed the project that funded the study, and wrote most of the paper. MB designed, supervised, and performed the statistical analysis. CD was in charge of field activities and contributed to the paper elaboration. AA was in charge of morphometric measurements, elaborated figures, and collaborated in information gathering and practical issues of the publication. All authors discussed the results and implications and commented on the manuscript at all stages.

Verónica Loewe-Muñoz

vloewe@infor.cl

1 Chilean Forestry Institute (INFOR), Sucre, 7750000 Santiago, Chile

2 CONICET Biometry Unit, College of Agriculture, Universidad Nacional de Córdoba, Ciudad Universitaria, CC509, 500 Córdoba, Argentina

\section{Introduction}

The nut-bearing stone pine (Pinus pinea $\mathrm{L}$.) is a well-known species for the high nutritional value of its edible nuts (commonly known as pine nuts or pinoli), being a good source of unsaturated high quality fats, protein, vitamins, minerals, and bioactive compounds (Bolling et al. 2011; Evaristo et al. 2013). Thus, pine nuts are highly appreciated and increasingly in demand by the food industry, reaching high prices worldwide (Fady et al. 2004; International Nut and Dried Fruits 2012). Despite their high demand and being one of the most important nut species in the world, it has not been domesticated nor have varieties or cultivars been defined or used for production purposes, with limited efforts having been made for its cultivation (Mutke et al. 2007). This lack of research could be attributed to its biological characteristics; in 
particular, the long reproductive cycle of this species (42 months) may lead to cone, ovule, or embryo abortion (Krannitz and Duralia 2004). Additionally, there is a cultural barrier to considering it as a fruit crop, since pine nuts are regarded as a non-wood forest product (Loewe 2016).

Currently, an important reduction in the stone pine production in European producer countries has been reported due to the attack of the insect Leptoglossus occidentalis Heidemann and, as a consequence, pine nut demand and prices have rapidly increased in the last few years (Lonja de Reus 2018). The species has shown a good agroecological adaptation in Chile (Loewe et al. 2015, 2016), where potential cultivation areas were assessed, with over 4.8 million hectares found suitable for pine nut cropping (Ávila et al. 2012). In this country, the species show good health but $L$. occidentalis has recently been detected (Faúndez et al. 2017). Furthermore, agroclimatic conditions are suitable for the species growth (Loewe et al. 2015) and fruiting (Loewe et al. 2016), and important efforts are being made to improve stone pine cropping to maximize pine nut production (Loewe and Delard 2012). This is particularly important because only a very small fraction of cone weight corresponds to pine nuts (Montero et al. 2008).

According to Gordo et al. (2012), cone quality is related to cone size and weight, since bigger cones are associated with a higher number of seeds (unshelled pine nuts), higher yield, and bigger pine nuts (shelled white pine nuts, the edible component). Thus, pine nut production depends upon three main variables: number of cones, cone weight, and cone to pine nut yield (percentage of total pine nut weight in relation to cone weight), all of them being affected by climatic conditions (Calama et al. 2007), especially by spring and summer rainfall. No reference had been found regarding stand age on fruit characteristics. However, Calama et al. (2011) reported a high inter-annual variability in cone production.

The importance of fruit variability studies, especially of those focusing on cone to pine nut yield, has been growing because of the increasing presence of empty and damaged seeds (Mutke et al. 2015a). This phenomenon has been attributed to damage associated with increasing droughts or phenological shifts due to climatic change (Mutke et al. 2014), as well as with the infestation with Leptoglossus occidentalis Heidemann (Mutke et al. 2012; Sousa et al. 2012). In the European Mediterranean, low precipitation and continental climate are expected to cause a decrease in tree growth and cone production (Gordo et al. 2005; Mutke et al. 2006; Calama et al. 2016).

Apparently, healthy cones may contain up to $50 \%$ of empty seeds (Mutke et al. 2014). This phenomenon has driven to a severe loss of seed yield since 2001, with drops in cone to seed yield from 17 to $5 \%$, and in cone to pine nut yield from 4 to $2 \%$, or even less. In Chile, where L. occidentalis have only been recently detected, the observed variability should not be confused with the effect of pest infestation. The decrease in cone to pine nut yield is particularly relevant because companies usually buy cones by their weight rather than by pine nut content; determining cone to pine nut yield has still not been possible to date, even though serious attempts have been made (Nunes et al. 2016).

In a cross-sectional study (at a specific point in time), we characterized cone production and fruit traits along a latitudinal gradient in Chile (Loewe et al. 2016). However, longitudinal studies (repeated observations performed over several years) in healthy plantations, important to estimate the relative contribution of temporal and spatial components of fruit trait variability, are still missing. Consequently, we hypothesized that cone to pine nut yield is stable along years and variable among sites. Accordingly, the main goals of this study were to evaluate morphometric fruit traits to determine: (1) interannual variability, (2) spatial variability, and (3) identifying fruit traits that impact on pine nut yield.

\section{Material and methods}

\subsection{Material}

Five non-irrigated plantations (Rosario, Cáhuil, Toconey, Mulchén and Antiquina) and one irrigated plantation (Quilvo) were chosen at random from the 36 stone pine plantations existent among the O'Higgins and Araucania regions, Chile, sampling a $16.6 \%$ of the species plantations in the area. The location of the plantations and 10-year (2003-2013) average climatic variables are presented in Table 1 and Fig. 1. Climatic data were obtained from the Chilean National Environmental Information System (www.dga.cl; www.inia.cl).

These six plantations were monitored during 6 years (winters 2010-2015). Since a previous study (Álvarez 2010) reported coefficient of variation smaller than $15 \%$ for most of the fruit traits within plantations in Chile, ten healthy 3-yearold cones were randomly harvested per plantation during each year. Cones were collected from different trees and immediately weighted (fresh weight); the standard methodology is reported by several authors (Calama and Montero 2007; Mutke et al. 2015b).

A total of 360 cones were processed at INFOR's laboratory to extract seeds (in-shell pine nuts) and pine nuts (Fig. 2). Cone size (length and diameter), seed number per cone as well as seed and pine nut size (length and diameter) and weight were measured in the lab following the procedures reported in Table 2. Seed yield and pine nut yield were determined using the expressions specified in the same table. Empty and damaged seeds were quantified to monitor fruit health.

Statistical analyses Mixed linear models (West et al. 2014) were fitted with each fruit trait as response variable (Table 2). Each mixed model included plantation (P) and year (Y) effects as random, as well as an error term associated to 
Table 1 Characterization of the studied stone pine plantations

\begin{tabular}{|c|c|c|c|c|c|c|c|}
\hline \multirow[t]{2}{*}{ Plantation } & \multirow{2}{*}{$\begin{array}{l}\text { Age } \\
\text { (years in 2015) }\end{array}$} & \multicolumn{3}{|c|}{ Geographical location } & \multirow{2}{*}{$\begin{array}{l}\text { Annual average } \\
\text { temperature }\left({ }^{\circ} \mathrm{C}\right)\end{array}$} & \multirow{2}{*}{$\begin{array}{l}\text { Autumn maximum } \\
\text { temperature }{ }^{\dagger}\left({ }^{\circ} \mathrm{C}\right)\end{array}$} & \multirow{2}{*}{$\begin{array}{l}\text { Annual rainfall } \\
(\mathrm{mm})\end{array}$} \\
\hline & & Latitude & Longitude & Altitude (m.a.s.l.) & & & \\
\hline Rosario & 20 & $34^{\circ} 20^{\prime} \mathrm{S}$ & $70^{\circ} 51^{\prime} \mathrm{W}$ & 352 & 13.6 & 18.6 & 300 \\
\hline Cáhuil & 32 & $34^{\circ} 29^{\prime} \mathrm{S}$ & $72^{\circ} 0^{\prime} \mathrm{W}$ & 116 & 13.2 & 18.7 & 382 \\
\hline Quilvo & 26 & $34^{\circ} 55^{\prime} \mathrm{S}$ & $71^{\circ} 7^{\prime} \mathrm{W}$ & 330 & 14.2 & 18.0 & $459^{*}$ \\
\hline Toconey & 22 & $35^{\circ} 24^{\prime} \mathrm{S}$ & $72^{\circ} 3^{\prime} \mathrm{W}$ & 56 & 14.2 & 20.1 & 570 \\
\hline Mulchén & 46 & $37^{\circ} 39^{\prime} \mathrm{S}$ & $72^{\circ} 15^{\prime} \mathrm{W}$ & 408 & 13.2 & 17.5 & 1150 \\
\hline Antiquina & 18 & $38^{\circ} 04^{\prime} \mathrm{S}$ & $73^{\circ} 23^{\prime} \mathrm{W}$ & 100 & 11.5 & 15.2 & 815 \\
\hline
\end{tabular}

*With irrigation in spring and summer

${ }^{\dagger}$ Autumn (March 21 to June 20) maximum temperature was found to be a significant variable for seed number per cone by Loewe et al. (2016)

Fig. 1 Latitudinal distribution of the stone pine plantations studied in Chile

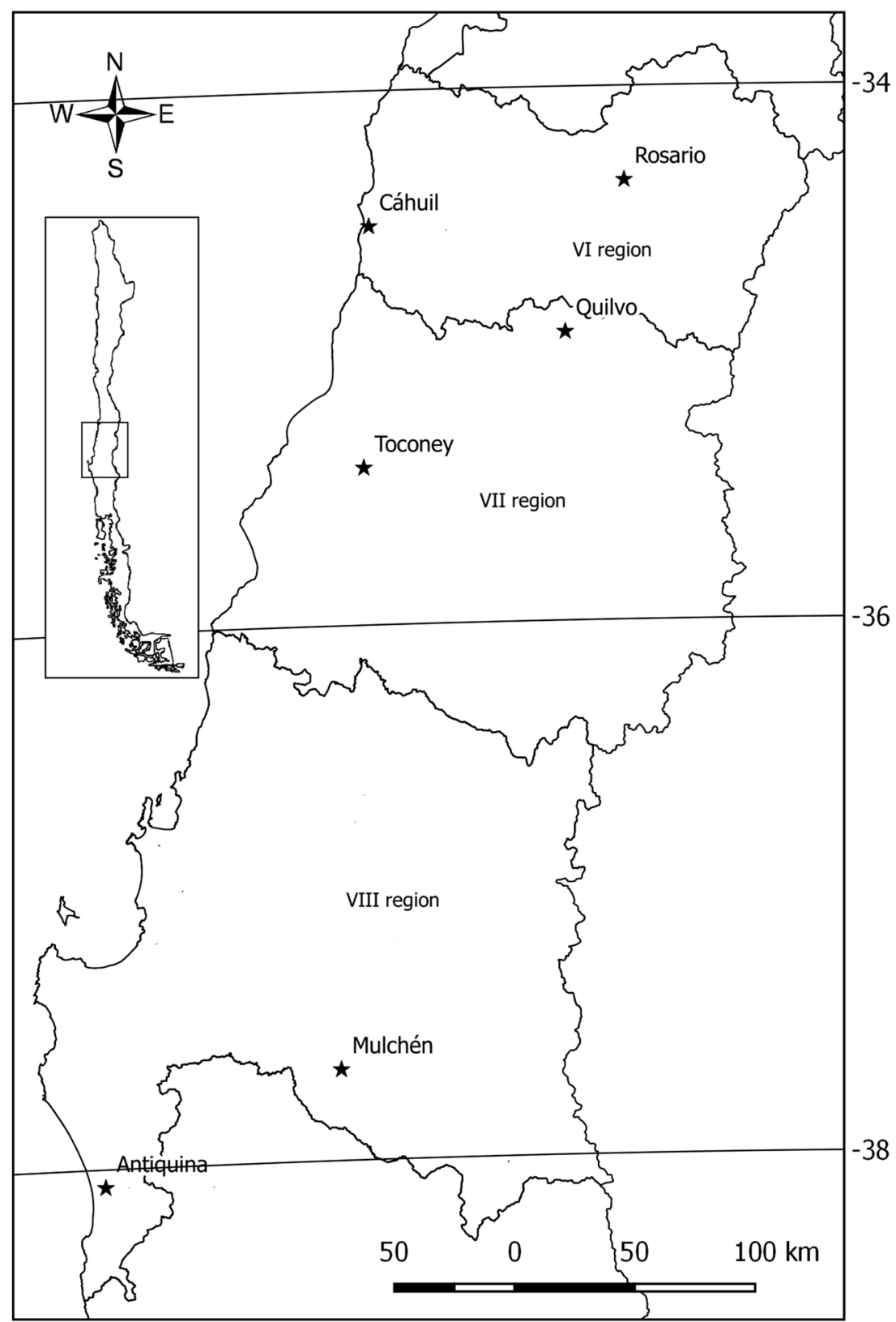




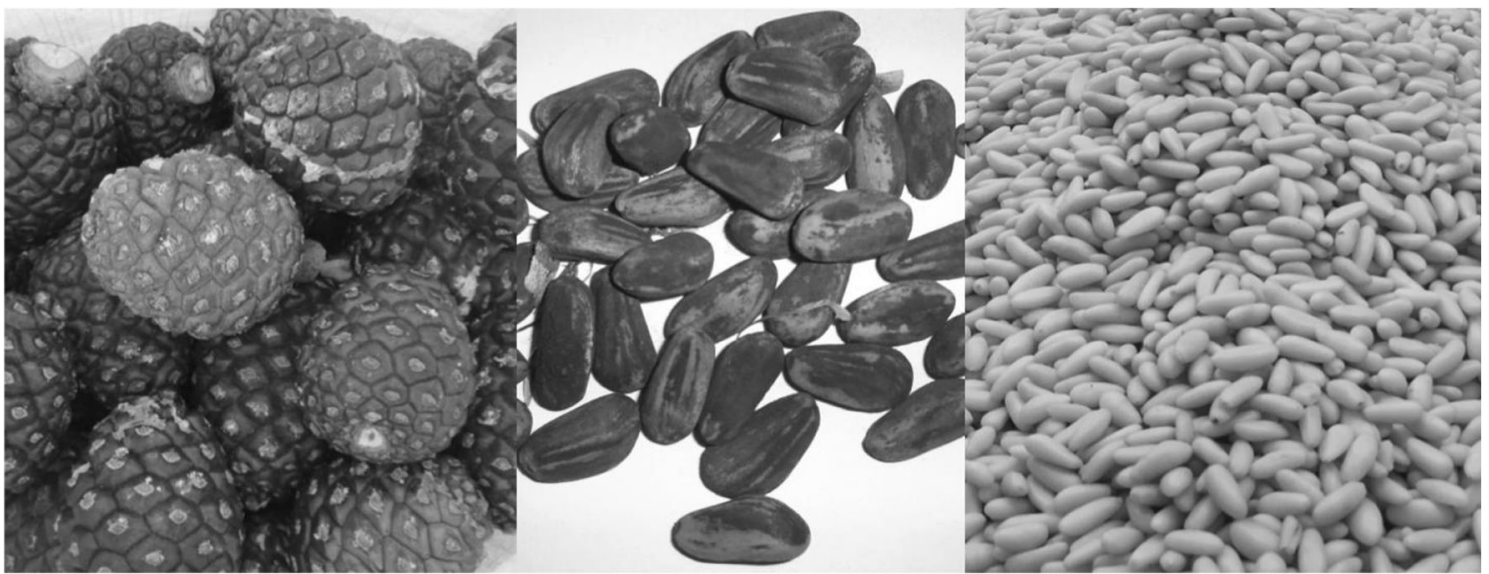

Fig. 2 Pinus pinea cones (left), seeds (center), and pine nuts (right)

residual variance. Restricted maximum likelihood (REML) estimates (Patterson and Thompson 1971) of P and Y effects were interpreted as indicator of spatial and temporal variability, respectively. The residual variability was interpreted as variability within plantation in a given year (residual). The estimated variance components were expressed as standard deviation between plantations, between years and within plantation, and as percentage of total variability.

In order to explore correlations among traits, the Pearson correlation coefficient (Pearson 1920) was calculated for each pair of fruit traits. Variability of pine nut yield (PY) as a function of morphometric traits was explored using a Classification and Regression Tree (CART) algorithm (Breiman et al. 1984) in order to identify the fruit trait that had most impact on PY. CART analysis creates a predictive model for a continuous response variable based on the recurrent classification of the studied cases into groups according to the values (threshold) of the predictor variables. The result of this recursive binary partitioning is a model whose structure can be displayed as a tree-like graph, with each split in the tree labeled according to the variable and threshold used for split definition. Additionally, we performed a non-parametric ANOVA (Conover 1999) to evaluate the statistical significance $(\alpha=0.05)$ of differences between groups suggested by the thresholds of the RT main nodes (nodes with more than 20 observations). Statistical analyses were performed using the software Infostat (Di Rienzo et al. 2015) and its interface with $R$ to run mixed linear models (www.r-project.org).

Table 2 Stone pine fruit traits

\begin{tabular}{|c|c|c|c|}
\hline Traits & Abbreviation & Unit & Measurement procedures \\
\hline Cone weight & $\mathrm{CW}$ & $\mathrm{g}$ & 3-year-old cones were weighted in a Mettler (Toledo, Spain) AJ150 \\
\hline Cone length & CL & $\mathrm{cm}$ & Measured with a digital caliper \\
\hline Cone diameter & $\mathrm{CD}$ & $\mathrm{cm}$ & Measured with a digital caliper in the largest section \\
\hline Seeds per cone & $\mathrm{SN}$ & No. & All seeds were extracted from each cone and counted \\
\hline Seed weight & SW & $\mathrm{g}$ & Each seed was weighted in a Mettler (Toledo, Spain) AJ150 \\
\hline Seed length & SL & $\mathrm{mm}$ & Measured with a digital caliper \\
\hline Seed diameter & SD & $\mathrm{mm}$ & Measured with a digital caliper in the largest section \\
\hline Seed yield & SY & $\%$ & $\mathrm{SY}=((\mathrm{SN} \times \mathrm{SW}) / \mathrm{CW}) \times 100$ \\
\hline Pine nuts per cone & $\mathrm{PN}$ & No. & All pine nuts from each cone were counted \\
\hline Pine nut weight & PW & g & Each pine nut was weighted in a Mettler (Toledo, Spain) AJ150 ${ }^{\dagger \dagger}$ \\
\hline Pine nut length & PL & $\mathrm{mm}$ & Measured with a digital caliper \\
\hline Pine nut diameter & $\mathrm{PD}$ & $\mathrm{mm}$ & Measured with a digital caliper in the largest section \\
\hline Pine nut yield & PY & $\%$ & $\mathrm{PY}=((\mathrm{PN} \times \mathrm{PW}) / \mathrm{CW}) \times 100$ \\
\hline Empty/damaged seeds & DS & $\%$ & $\mathrm{DS}=(\mathrm{SN}-\mathrm{PN}) / \mathrm{SN}$ \\
\hline
\end{tabular}

${ }^{\dagger}$ Fresh weight at harvest

${ }^{\dagger}$ Previously pine nuts were dried to $6 \%$ of humidity at $40{ }^{\circ} \mathrm{C}$ in a Red Line Binder oven (Tuttlingen, Germany) 


\section{Results}

Pine nut yield, which includes pine nut weight (PW) and pine nuts per cone $(\mathrm{PN})$, as well as cone weight $(\mathrm{CW})$ as components, was high in all plantations, ranging from 3.6 to $5 \%$ (Table 3). Quilvo had the biggest and heaviest cones $(675.9 \mathrm{~g})$ and pine nuts $(0.27 \mathrm{~g})$ and a PY of $4.7 \%$. Antiquina had the highest seeds per cone (SN) (125.7 units) and PN (116.8 units), but the smallest seed weight (SW) $(0.67 \mathrm{~g})$ and PW $(0.15 \mathrm{~g})$, and an average PY value of 4.1\%. In Rosario, with the lowest PN (94.6 units), the highest PY (5.0\%) was observed, with a PW high in relation to CW. Damaged seeds (DS) reached $9.2 \%$ on average, ranging from $5.4 \%$ in Quilvo to $13.8 \%$ in Toconey.

The correlation analysis (Table 4) showed that PY was positively correlated to number and size of pine nuts and negatively correlated to DS. Meanwhile, CW and cone size (CD and $\mathrm{CL}$ ) were positively correlated to most of the morphometric characteristics, but not to PY. SN was positively correlated to seed yield (SY), PN, and PY. PW was correlated to all fruit traits, with the exception of SN, PN, and DS.

The variance component estimated from the fitted mixed model analysis indicated that PY had a higher inter-annual variability ( $41.3 \%$ of total variability) than spatial or across plantations variability (4.7\%). Number and size of seeds and pine nuts also showed high inter-annual variability (44.8 and $77.3 \%$ respectively). Moreover, SN, PN, and DS, and consequently PY, showed high variability within plantations in a single year (over 50\%). However, SW and PW had a higher variability across plantations than across years, with these traits being the least affected by inter-annual variability (Table 5). As found for PY, SY also showed a higher temporal variability than spatial variability ( $34.6 \%$ vs $3.8 \%$ ).

DS had a very high inter-annual variability $(41.5 \%)$ and high variability within plantations in a single year (58.5\%). Morphometric cone traits showed high inter-annual variation $(>40 \%)$.
PY variability as a function of fruit traits considering all cones and explored by CART analysis showed that PN and PW were the most influential variables to determine PY (Fig. 3). A threshold of 78.2 PN was found showing that the $\mathrm{PY}$ of cones with more than this value had a relatively high value. Differences of PY between cones with PN below or above that threshold (2.7 vs $4.4 \%$ ) were statistically significant $(p<0.0001)$. Pine nut yield, expressed as kernel weight (g) per cone weight $(\mathrm{kg})$, was $17 \mathrm{~g} \mathrm{~kg}^{-1}$ higher on average in cones with more than 78 pine nuts than in the opposite case (Fig. 4). For PW, a threshold of $0.135 \mathrm{~g}$ was detected with statistical differences $(p<0.0001)$ in PY between cones containing pine nuts lighter or heavier than this threshold. PY was $58.6 \%$ higher when PW was above this threshold (4.6 vs $2.9 \%)$.

\section{Discussion}

The results of this study showed that stone pine PY values in Chile (3.6 to 5.0\%) are at least equal to the $3.6 \%$ reported for Italy in 1910 (Peruzzi et al. 1998), and higher than those recorded in the Valladolid area, Spain, which ranged between 2.7 and $4.4 \%$ in $1996 / 1997$ and have drastically decreased recently (1.8\% in $2012 / 2013$ and $2.1 \%$ in $2013 / 2014$ ) (Calama et al. 2014). Chilean PY values were also higher than those recorded in Cataluña (1.1\%) and Meseta Norte $(2.1 \%)$ in 2013/2014 (Calama et al. 2015) and in Portugal (1.7\%) in 2003/2004 (Evaristo et al. 2008). This could be due to the absence of negative effects of Leptoglossus occidentalis Heidemann in Chile so far, and to the adequate climatic characteristics of the area in which stone pine is cultivated, especially the low hydric deficit which is the variable that best explains the quantity of seeds per cone (PN) according to Loewe et al. (2016), which coincidently in this study is also the best indicator for predicting PY.

Table 3 Stone pine fruit traits by plantation (average of 6 years, 2010-2015)

\begin{tabular}{|c|c|c|c|c|c|c|c|c|c|c|c|c|c|c|}
\hline \multirow[t]{2}{*}{ Plantation } & \multicolumn{3}{|l|}{ Cone } & \multicolumn{6}{|l|}{ Seed } & \multicolumn{5}{|c|}{ Pine nut } \\
\hline & $\begin{array}{l}\text { CW } \\
\mathrm{g}\end{array}$ & $\begin{array}{l}\mathrm{CL} \\
\mathrm{cm}\end{array}$ & $\begin{array}{l}\mathrm{CD} \\
\mathrm{cm}\end{array}$ & $\begin{array}{l}\text { SN } \\
\text { no. }\end{array}$ & $\begin{array}{l}\text { SW } \\
\mathrm{g}\end{array}$ & $\begin{array}{l}\mathrm{SL} \\
\mathrm{mm}\end{array}$ & $\begin{array}{l}\mathrm{SD} \\
\mathrm{mm}\end{array}$ & $\begin{array}{l}\text { SY } \\
\%\end{array}$ & $\begin{array}{l}\text { DS } \\
\%\end{array}$ & $\begin{array}{l}\text { PN } \\
\text { no. }\end{array}$ & $\begin{array}{l}\text { PW } \\
\text { g }\end{array}$ & $\begin{array}{l}\text { PL } \\
\mathrm{mm}\end{array}$ & $\begin{array}{l}\text { PD } \\
\mathrm{mm}\end{array}$ & $\begin{array}{l}\text { PY } \\
\%\end{array}$ \\
\hline Rosario & 436.0 & 10.0 & 10.3 & 107.0 & 0.88 & 18.6 & 9.3 & 21.7 & 10.9 & 94.6 & 0.23 & 14.0 & 5.6 & 5.0 \\
\hline Cáhuil & 474.3 & 11.2 & 9.0 & 107.9 & 0.77 & 17.1 & 8.6 & 17.7 & 10.2 & 96.9 & 0.18 & 12.2 & 4.7 & 3.6 \\
\hline Quilvo & 675.9 & 14.7 & 11.7 & 118.8 & 1.23 & 21.0 & 10.2 & 22.6 & 5.4 & 112.6 & 0.27 & 15.5 & 5.7 & 4.7 \\
\hline Toconey & 466.4 & 11.3 & 8.6 & 109.8 & 0.76 & 16.5 & 8.4 & 17.8 & 13.8 & 97.0 & 0.22 & 12.6 & 4.7 & 4.6 \\
\hline Mulchén & 635.8 & 13.0 & 9.8 & 109.4 & 1.08 & 19.0 & 10.0 & 18.7 & 7.1 & 100.2 & 0.25 & 13.3 & 5.8 & 3.9 \\
\hline Antiquina & 436.7 & 12.2 & 8.9 & 125.7 & 0.67 & 15.8 & 8.3 & 19.3 & 7.6 & 116.8 & 0.15 & 14.3 & 5.4 & 4.1 \\
\hline Overall mean & 520.8 & 12.1 & 9.7 & 113.1 & 0.90 & 18.0 & 9.1 & 19.6 & 9.2 & 103.0 & 0.22 & 13.6 & 5.3 & 4.3 \\
\hline
\end{tabular}

$C W$ cone weight, $C L$ cone length, $C D$ cone diameter, $S N$ seeds per cone, $S W$ seed weight, $S L$ seed length, $S D$ seed diameter, $S Y$ seed yield, $D S$ empty/ damaged seeds, $P N$ pine nuts per cone, $P W$ pine nut weight, $P L$ pine nut length, $P D$ pine nut diameter, $P Y$ pine nut yield 
Table 4 Stone pine fruit traits correlations

\begin{tabular}{|c|c|c|c|c|c|c|c|c|c|c|c|c|c|}
\hline & $\mathrm{CW}$ & CL & $\mathrm{CD}$ & SN & SW & SL & SD & SY & DS & $\mathrm{PN}$ & PW & PL & PD \\
\hline CL & $0.73 *$ & & & & & & & & & & & & \\
\hline $\mathrm{CD}$ & $0.57 *$ & $0.68 *$ & & & & & & & & & & & \\
\hline $\mathrm{SN}$ & $0.41 *$ & $0.46^{*}$ & $0.27^{*}$ & & & & & & & & & & \\
\hline SW & $0.69 *$ & $0.50 *$ & $0.50 *$ & 0.03 & & & & & & & & & \\
\hline SL & $0.47 *$ & $0.38^{*}$ & $0.54 *$ & -0.07 & $0.61 *$ & & & & & & & & \\
\hline SD & $0.38 *$ & $0.29 *$ & $0.44 *$ & $-0.17 *$ & $0.44 *$ & $0.82 *$ & & & & & & & \\
\hline SY & -0.01 & $0.15^{*}$ & $0.17 *$ & $0.50 *$ & $0.37^{*}$ & 0.08 & -0.11 & & & & & & \\
\hline DS & $-0.17^{*}$ & -0.08 & 0.08 & $-0.16^{*}$ & -0.10 & -0.10 & 0.002 & -0.04 & & & & & \\
\hline $\mathrm{PN}$ & $0.41^{*}$ & $0.42 *$ & $0.19 *$ & $0.89 *$ & 0.05 & -0.05 & $-0.15^{*}$ & $0.42 *$ & $-0.57 *$ & & & & \\
\hline PW & $0.53 *$ & $0.36^{*}$ & $0.36^{*}$ & -0.06 & $0.75^{*}$ & $0.48^{*}$ & $0.35^{*}$ & $0.21^{*}$ & 0.03 & -0.08 & & & \\
\hline PL & $0.20 *$ & $0.20 *$ & $0.35^{*}$ & 0.004 & $0.31 *$ & $0.42 *$ & $0.41 *$ & $0.14 *$ & -0.12 & 0.04 & $0.31 *$ & & \\
\hline PD & -0.002 & 0.04 & $0.18^{*}$ & $-0.23^{*}$ & $0.14 *$ & $0.36^{*}$ & $0.51 *$ & -0.06 & -0.06 & $-0.18^{*}$ & $0.18 *$ & $0.61 *$ & \\
\hline PY & -0.13 & -0.02 & -0.09 & $0.37^{*}$ & 0.05 & -0.07 & $-0.22 *$ & $0.62 *$ & $-0.37 *$ & $0.46^{*}$ & $0.36^{*}$ & $0.15^{*}$ & 0.02 \\
\hline
\end{tabular}

$C W$ cone weight, $C L$ cone length, $C D$ cone diameter, $S N$ seeds per cone, $S W$ seed weight, $S L$ seed length, $S D$ seed diameter, $S Y$ seed yield, $D S$ empty/ damaged seeds, $P N$ pine nuts per cone, $P W$ pine nut weight, $P L$ pine nut length, $P D$ pine nut diameter, $P Y$ pine nut yield

*Statistically significant correlation among traits $(p<0.05)$

Cone weight, an important quality attribute in most fruit crops (Wetzstein et al. 2011), reached a high average value $(521 \mathrm{~g})$, confirming what previously reported by Loewe et al. (2016). In fact, cones in Chile are heavier than in Tunisia (Boutheina et al. 2013), Portugal (Evaristo et al. 2008; Gonçalves and Pommerening 2012) and Spain (Gordo et al. 2012; Mutke et al. 2012). However, the studied plantation with lowest cone weight (436 g) had the highest PY; therefore, $\mathrm{CW}$ by itself should not be used as the unique fruit indicator of PY. Our results showed that the average number of pine nuts per cone is a key trait in determining PY. In average, we measured 103 pine nuts per cone, a higher value than those reported in Turkey (Bilir 2009), Italy (Ciancio et al. 1990), and Portugal (Evaristo et al. 2008; Calama et al. 2015).

Furthermore, the variance component analysis showed that the PY inter-annual variability was high $(41.3 \%)$ probably caused by the impact of meteorological variations on $\mathrm{CW}$ and SN. Loewe et al. (2016) showed that the annual average temperature, annual rainfall and hydric deficit significantly affect $\mathrm{CW}$, and autumn maximum temperature and hydric deficit impact SN. PY within-plantation variability was also high (54\%), and related to high SN and PN variability between 3-year-old cones from the same plantation. By contrast, Montero et al. (2008) indicated that despite large spatial and temporal variability in cone production, PY remains almost constant.

In agreement with Mutke et al. (2005) and Calama et al. (2007), we found a high inter-annual variability also in CW (46\%). The relationship between climate and CW was reported in a previous study conducted in numerous plantations across Chile (Loewe et al. 2016), where annual average temperature and annual rainfall were found to be positively

Table 5 Stone pine fruit trait variance components (expressed as standard deviation and percentage of total variability between parentheses)

\begin{tabular}{|c|c|c|c|c|c|c|c|c|c|c|c|c|c|c|}
\hline \multirow[t]{2}{*}{ Effect } & \multicolumn{3}{|l|}{ Cone } & \multicolumn{6}{|l|}{ Seed } & \multicolumn{5}{|c|}{ Pine nut } \\
\hline & $\begin{array}{l}\text { CW } \\
\mathrm{g}\end{array}$ & $\begin{array}{l}\mathrm{CL} \\
\mathrm{cm}\end{array}$ & $\begin{array}{l}\mathrm{CD} \\
\mathrm{cm}\end{array}$ & $\begin{array}{l}\text { SN } \\
\text { no. }\end{array}$ & $\begin{array}{l}\text { SW } \\
\text { g }\end{array}$ & $\begin{array}{l}\mathrm{SL} \\
\mathrm{mm}\end{array}$ & $\begin{array}{l}\mathrm{SD} \\
\mathrm{mm}\end{array}$ & $\begin{array}{l}\text { SY } \\
\%\end{array}$ & $\begin{array}{l}\text { DS } \\
\%\end{array}$ & $\begin{array}{l}\text { PN } \\
\text { no. }\end{array}$ & $\begin{array}{l}\text { PW } \\
\text { g }\end{array}$ & $\begin{array}{l}\mathrm{PL} \\
\mathrm{mm}\end{array}$ & $\begin{array}{l}\mathrm{PD} \\
\mathrm{mm}\end{array}$ & $\begin{array}{l}\text { PY } \\
\%\end{array}$ \\
\hline $\mathrm{P}$ & $\begin{array}{l}87.3 \\
(26.8)\end{array}$ & $\begin{array}{l}1.4 \\
(36.8)\end{array}$ & $\begin{array}{l}0.9 \\
(26.3)\end{array}$ & $\begin{array}{l}0.0 \\
(0.0)\end{array}$ & $\begin{array}{l}0.2 \\
(54.2)\end{array}$ & $\begin{array}{l}1.6 \\
(32.8)\end{array}$ & $\begin{array}{l}0.5 \\
(10.1)\end{array}$ & $\begin{array}{l}0.0 \\
(3.8)\end{array}$ & $\begin{array}{l}<0.01 \\
(0.0)\end{array}$ & $\begin{array}{l}1.9 \\
(0.4)\end{array}$ & $\begin{array}{l}0.0 \\
(47.1)\end{array}$ & $\begin{array}{l}0.5 \\
(4.1)\end{array}$ & $\begin{array}{l}<0.01 \\
(0.0)\end{array}$ & $\begin{array}{l}0.3 \\
(4.7)\end{array}$ \\
\hline Y & $\begin{array}{l}114.2 \\
(46.0)\end{array}$ & $\begin{array}{l}1.4 \\
(40.1)\end{array}$ & $\begin{array}{l}1.3 \\
(59.3)\end{array}$ & $\begin{array}{l}17.6 \\
(44.8)\end{array}$ & $\begin{array}{l}0.1 \\
(22.9)\end{array}$ & $\begin{array}{l}2.0 \\
(52.2)\end{array}$ & $\begin{array}{l}1.3 \\
(75.7)\end{array}$ & $\begin{array}{l}0.0 \\
(34.6)\end{array}$ & $\begin{array}{l}7.7 \\
(41.5)\end{array}$ & $\begin{array}{l}18.5 \\
(44.9)\end{array}$ & $\begin{array}{l}0.0 \\
(26.5)\end{array}$ & $\begin{array}{l}2.2 \\
(77.3)\end{array}$ & $\begin{array}{l}1.1 \\
(62.3)\end{array}$ & $\begin{array}{l}0.8 \\
(41.3)\end{array}$ \\
\hline Residual & $\begin{array}{l}87.9 \\
(27.2)\end{array}$ & $\begin{array}{l}1.1 \\
(23.2)\end{array}$ & $\begin{array}{l}0.7 \\
(14.4)\end{array}$ & $\begin{array}{l}19.5 \\
(55.2)\end{array}$ & $\begin{array}{l}0.1 \\
(22.9)\end{array}$ & $\begin{array}{l}1.1 \\
(15.0)\end{array}$ & $\begin{array}{l}0.6 \\
(14.2)\end{array}$ & $\begin{array}{l}0.0 \\
(61.5)\end{array}$ & $\begin{array}{l}9.1 \\
(58.5)\end{array}$ & $\begin{array}{l}20.4 \\
(54.6)\end{array}$ & $\begin{array}{l}0.0 \\
(26.5)\end{array}$ & $\begin{array}{l}1.1 \\
(18.6)\end{array}$ & $\begin{array}{l}0.8 \\
(37.7)\end{array}$ & $\begin{array}{l}1.0 \\
(54.0)\end{array}$ \\
\hline
\end{tabular}

$C W$ cone weight, $C L$ cone length, $C D$ cone diameter, $S N$ seeds per cone, $S W$ seed weight, $S L$ seed length, $S D$ seed diameter, $S Y$ seed yield, $D S$ empty/ damaged seeds, $P N$ pine nuts per cone, $P W$ pine nut weight, $P L$ pine nut length, $P D$ pine nut diameter, $P Y$ pine nut yield, $P$ plantation effect (spatial variability), $Y$ year within plantations effect (inter annual variability), Residual variability within combination of plantation and year 
Fig. 3 Stone pine fruit traits that best explain cone to kernel yield. Average PY for each node is reported in the embedded table. $\mathrm{PN}$ pine nuts per cone, $\mathrm{PW}$ pine nut weight, PY pine nut yield

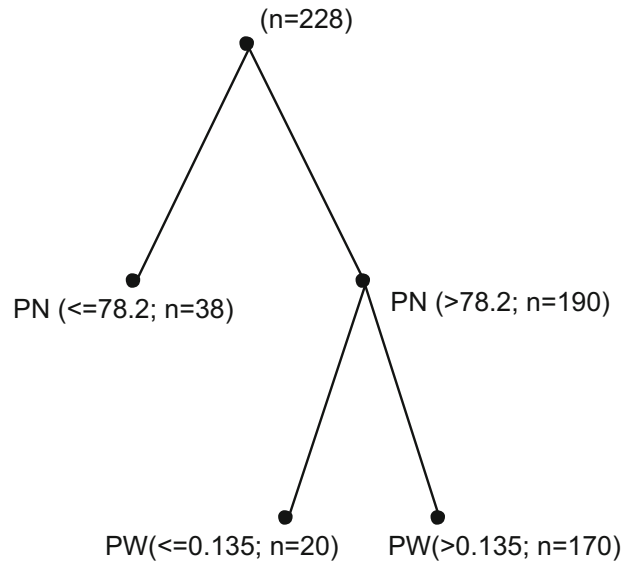

correlated with this fruit trait and with high maximum temperature during embryo development (a favorable factor). Interestingly, a higher $\mathrm{CW}$ did not translate into a higher PY, and a lower CW does not necessarily translate into a lower PY, in agreement with Calama et al. (2015), who stated that there is no effect of CW on PY. For example, the plantation in Rosario, with the lowest CW, had the highest yield (5.0\%). This indicates that selecting cones by weight will not improve PY, as also indicated for pomegranate (Wetzstein et al. 2011), a species whose fruit is formed from one flower and contains several seeds, as it also occurs in stone pine. In fact, our results showed that PN is the most determining variable for PY. High values of PN are highly required to enhance cone filling, as indicated for other crops such as wheat (Wiegand and Cuellar 1981; Fischer et al. 1977), maize (Borrás and Otegui 2001; Otegui et al. 1995), rice (García et al. 2010), sunflower (Mercau et al. 2001), and peanut (Giayetto et al. 2012; Phakamas et al. 2008), even though maximum weight is not reached.

In fact, a partial correlation between the number of pine nuts and its weight has been reported in many crop species (Grashoff and D’Antuono 1997; Board et al. 1999; Borrás and Otegui 2001; Zapata et al. 2004; Phakamas et al. 2008). The average number of pine nuts per cone reported in this work (103) was similar to the value reported by Álvarez (2010)
(107), with almost no variation across plantations $(0.4 \%)$ but high variation among years $(44.9 \%)$ and within plantations in the same year (54.6\%). An increase of more than $60 \%$ (as shown in Fig. 3) in PY was detected in cones that contained more than 78 pine nuts. Therefore, cones with many pine nuts will be those with the highest PY. However, PY was also associated to the weight of pine nuts, which is positively correlated with a high PY. PW was on average $0.22 \mathrm{~g}$ and showed high spatial variability $(47.1 \%)$. Plantations with biggest and heaviest cones were also those with highest PW, in agreement with Calama et al. (2015).

Regarding cone to seed yield, we observed an average of $19.6 \%$ (ranging from 17.7 to $22.6 \%$ ), similar to the value reported in Portugal (19.2\%) (Silveira 2012) and in Italy (20 to $26 \%$ ) (Ciancio et al. 1990) before the arrival of L. occidentalis from the USA. In Chile, we found a greater SY temporal variation than spatial variation (34.6 vs $61.5 \%$, respectively). Calama et al. (2014) reported values between 8.8 and $18.2 \%$ for the inter-annual variability of this trait. Moreover, our results indicate that SY is also highly variable within plantations in a given year $(61.5 \%)$. SY was found to be positively correlated to seed number and weight, as indicated by Gordo et al. (2012). According to our results, SY was not correlated to empty or damaged seeds, probably due to the healthy condition of the species in Chile (González 2012),
Fig. 4 Fruit morphometric traits affecting cone to pine nut yield in stone pine plantations. Each threshold was detected by Regression Tree analysis.

Different letters indicate statistical differences between groups of pine nuts $(p<0.0001)$
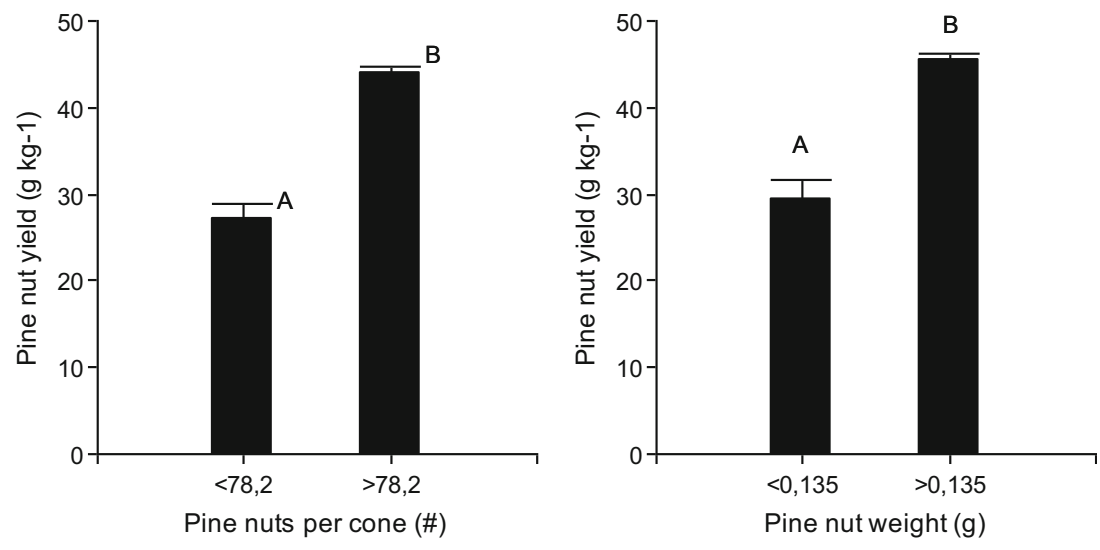
where L. occidentalis only recently has been detected (Faúndez et al. 2017). In fact, no damages to the endosperm with developed embryo, classified as type II by Calama et al. (2015), were observed. Total non-viable seeds reached on average $9.2 \%$, lower than values reported in Croatia (10.8\% and $4.6 \%$ of empty and rotten seeds, respectively) (Jakovljevic et al. 2009), in Tunisia (19.3\%) (Boutheina et al. 2013) and in Spain, where empty seeds have increased from below $10 \%$ (Sousa et al. 2012) to 50\% (Mutke et al. 2016) or even 60\% (Calama et al. 2017). The increasing presence of non-viable seeds has been related to the attack of $L$. occidentalis (Calama et al. 2015) and to climatic variables such as annual rainfall (Calama et al. 2014). Our results showed that this trait was highly variable among cones even within the same plantation.

SW ( $0.9 \mathrm{~g}$ on average) was higher than the 0.4 to $0.6 \mathrm{~g}$ reported by other authors (Mutke et al. 2012; Calama et al. 2014) which could be due to the cooler habitat that allows the species to live even with a lower hydric availability (Loewe et al. 2015) and to show a high cone yield in Chile (Loewe et al. 2016). Our study showed more SW spatial than temporal variability ( 54.2 vs $22.9 \%$ ). High inter-annual variability of SW has been reported in Spain (Calama et al. 2014). SW variation was correlated to SY in our study as Mutke et al. (2005) reported, but SW variation was not correlated to PY.

Given the PN high inter-annual and within plantation variability, and since it is the main determinant in PY, practices oriented to increase average values and reduce variability in PN might increase PY. Therefore, PN should be a characteristic of tree selection in the species breeding programs. Additionally, cultivation practices such as irrigation (Lobell et al. 2005) and fertilization (Loewe and Delard 2015), which increases PN, should be further explored to improve PY.

To our knowledge, no studied have reported the variables impacting pine nut number per cone. The closest information comes from Loewe et al. (2016) who identified climatic variables that significantly influence seed number per cone (annual water deficit and the autumn maximum temperature) and also the biometeorological variables that account for physiophenological phases involved in this trait determination (accumulated rainfall during induction of male primordia; maximum average temperature during 2-year-old cone growth, and accumulated rainfall during 3-year-old cone growth and cone ripening). Since pine nut number per cone is so determinant in PY, we suggest addressing in future studies both climatic variables and cultivation practices that could help in maximizing pine nut number in stone pine cones.

\section{Conclusions}

Cone to pine nut yield, an important commercial feature of stone pine cropping, ranged from 3.6 to $5 \%$ in Chile, higher values than the current values reported in the main pine nut producing countries. The most important fruit trait in determining PY was pine nut number per cone, followed by pine nut weight. PY showed both a high inter-annual variability and within plantation variability, similarly to $\mathrm{PN}$, whereas PW showed more spatial than temporal variability. PY was not correlated to cone weight and size. Cone morphometry is not a good indicator of PY, and thus, selecting cones for size or weight will not improve cone to pine nut yield.

Acknowledgements We thank Aldo Salinas and Andrés Bello for the assistance with cone harvesting and to the plantation owners for allowing the access to the material.

Funding This work was supported by FONDEF, CONICYT, and Chilean Ministry of Education (grant code D11I1134).

Data availability The datasets generated and analyzed during the current study are not publicly available due to institutional guidelines but are available from the corresponding author on reasonable request.

\section{Compliance with ethical standards}

Conflict of interest The authors declare that they have no conflict of interest.

\section{References}

Álvarez A. (2010). Caracterización de frutos de pino piñonero (Pinus pinea L.), producidos en localidades establecidas desde la región de Valparaíso hasta la Región de La Araucanía de Chile. Tesis para optar al título de Ingeniero Agrónomo, Universidad Iberoamericana de Ciencias y Tecnología, Santiago, Chile: 77

Ávila A, Delard C, Loewe V (2012) Potential zones for stone pine (Pinus pinea L.) in Chile. In: Sustaining humans and forests in changing landscapes: forests, society and global change. IUFRO Landscape Ecology Working Party Conference. Concepción, Chile

Bilir N (2009) Cone, seed and nut characters in Pinus pinea. International Convention Center "Seed orchards and the link to long-term tree breeding in response to climate change", Jeju, Korea. 8-11/9/2009. IUFRO. Forestry Faculty, Suleyman Demirel University, Isparta, Turkey

Board JE, Kang MS, Harville BG (1999) Path analyses of the yield formation process for late-planted soybean. Agron J 91(1):128-135

Bolling BW, Oliver CY, McKay DL, Blumberg JB (2011) Tree nut phytochemicals: composition, antioxidant capacity, bioactivity, impact factors: a systematic review of almonds, Brazils, cashews, hazelnuts, macadamias, pecans, pine nuts, pistachios and walnuts. Nutr Res Rev 24:244-275

Borrás L, Otegui ME (2001) Maize kernel weight response to post flowering source-sink ratio. Crop Sci 41(6):1816-1822

Boutheina A, El Aouni MH, Balandier P (2013) Influence of stand and tree attributes and silviculture on cone and seed productions in forests of Pinus pinea L. in northern Tunisia. Mediterranean Stone Pine for Agroforestry. Options Méditerranéennes Série A. Séminaires Méditerranéens 105:9-14

Breiman L, Friedman JH, Olshen RA, Stone CJ (1984) Classification and regression trees. Chapman \& Hall/CRC, Boca Raton

Calama R, Montero G (2007) Cone and seed production from Stone pine (Pinus pinea L.) stands in Central Range (Spain). Eur J For Res 126(1):23-35. https://doi.org/10.1007/s10342-005-0100-8 
Calama R, Mutke S, Sánchez M, Garriga E, Montero G (2007) Modelling spatial and temporal variability on Stone pine (Pinus pinea L.) cone quality: preliminary results. EFIMED Scientific Seminar: modelling, valuing and managing Mediterranean forest ecosystem for non-timber goods and services. S.1.: CIFOR-INIA

Calama R, Mutke S, Tomé J, Gordo J, Montero G, Tomé M (2011) Modelling spatial and temporal variability in a zero-inflated variable: the case of stone pine (Pinus pinea L.) cone production. Ecol Model 222:606-618

Calama R, Gordo J, Conde M, Madrigal G, Mutke S, Pardos M, Garriga E, Montero G, Finat L, Martín R, Cubero D (2014) Pérdidas de rendimiento de piña y piñón en las masas de Pinus pinea. Jornada Presentación Proyecto PROPINEA. Pedrajas de San Esteban November 21, 2014. Spain

Calama R, Gordo J, Conde M, Madrigal G, Mutke S, Pardos M, Garriga E, Montero G, Fontes L (2015) Rendimiento de piñón en piña de Pinus pinea en Portugal: caracterización y comparación con otras regiones. Seminario UNAC "Avanços no conhecimento na fileira do Pinheiro manso" March 2015. Alcácer do Sal: UNAC

Calama R, Gordo J, Madrigal G, Conde M, Bravo-Oviedo A, López E, Gallardo C, de Dios-García J, Montero G, Vázquez-Piqué J, Prados M (2016) Cone production in Pinus pinea forests facing climate change: proposals for adaptive management. International Conference on Wild Forest Products in Europe. Barcelona, Spain, October 13-14

Calama R, Gordo J, Mutke S, Madrigal G, Conde M, Raposo R, Recuenco M, Pardos M (2017) Variabilidad espacio temporal en el daño asociado a Leptoglossus occidentalis en pinares de Pinus pinea de la provincia de Valladolid. Poster presented at the $7^{\circ}$ Spanish Forest Congress. Plasencia, 26-30 June 2017

Ciancio O, Cutini A, Mercurio R, Veracini A (1990) Un modele sylvicole pour la conservation et l'amélioration de la pinede de Pin pignon d'Alberese (Toscane, Italie). Forêt Médit XII(2):130-142

Conover WJ (1999) Practical nonparametric statistics, 3rd edn. Wiley, Hoboken, NJ ISBN: 978-047116068-7. 592 p

Di Rienzo JA, Casanoves F, Balzarini MG, Gonzalez L, Tablada M, Robledo CW (2015) InfoStat version 2015. Grupo InfoStat, FCA, Universidad Nacional de Córdoba, Argentina. Available at http:// www.infostat.com.ar. Accessed 2 July 2015

Evaristo I, Tenreiro R, Costa R (2008) Caracterização de parâmetros biométricos e de ácidos gordos em pinhões de populações portuguesas de Pinus pinea. Silva Lusit 16(1):1-19

Evaristo I, Batista D, Correia I, Correia P, Costa R (2013) Chemical profiling of Portuguese Pinus pinea L. nuts and comparative analysis with P. koraiensis Sieb. \& Zucc. commercial kernels. Options Méditérr 105:99-104

Fady B, Fineschi S, Vendramin GG (2004) EUFORGEN technical guidelines for genetic conservation and use of Italian Stone pine (Pinus pinea). International Plant Genetic Resources Institute, Roma: 6. Available at http://www.bioversityinternational.org/uploads/tx news/Italian_stone_pine_Pinus_pinea_1036.pdf. Accessed Feb 122014

Faúndez E, Rocca J, Villablanca J (2017) Detection of the invasive western conifer seed bug Leptoglossus occidentalis Heidemann, 1910 (Heteroptera: Coreidae: Coreinae) in Chile. Arquivos Entomolóxicos 17:317-320

Fischer RA, Aguilar I, Laing DR (1977) Post-anthesis sink size in a highyielding dwarf wheat: yield response to grain number. Aust J Agric Res 28(2): $165-175$

García A, Dorado M, Pérez I, Montilla E (2010) Efecto del déficit hídrico sobre la distribución de fotoasimilados en plantas de arroz (Orysa sativa $\mathrm{L}$.). Interciencia $35(1)$

Giayetto O, Fernandez E, Cerioni G, Morla F, Rosso M, Kearney M, Violante M (2012) Caracterización ecofisiológica de genotipos de maní (Arachis hypogaea L.) en Córdoba, Argentina. Ciencia y Tecnología de los Cultivos Industriales 1(3):201-211
Gonçalves AC, Pommerening A (2012) Spatial dynamics of cone production in Mediterranean climates: a case study of Pinus pinea L. in Portugal. For Ecol Manag 266:83-93

González GM (2012) Principales plagas que afectan los frutos de pino piñonero (Pinus pinea L.). Informativo Sanitario, Santiago, Chile $6 \mathrm{p}$

Gordo AJ, Mutke S, Gil L (2005) Consecuencias del cambio climático en la producción de piña en los pinares continentales de Pinus pinea $\mathrm{L}$. In Actas del IV Congreso Forestal Español (pp. 1-7). Retrieved from http://www.secforestales.org/buscador/pdf/4CFE05-029.pdf

Gordo J, Calama R, Pardos M, Bravo F, Montero G (ed.) (2012) La regeneración natural de los pinares en los arenales de la Meseta Castellana. Valladolid, Spain: Instituto Universitario de Investigación en Gestión Forestal Sostenible, Universidad de Valladolid, INIA. Available in: http://www.pfcyl.es/sites/default/ files/biblioteca/regeneracion pinares.pdf. Accessed August 16 2013

Grashoff C, D'Antuono LF (1997) Effect of shading and nitrogen application on yield, grain size distribution and concentrations of nitrogen and water soluble carbohydrates in malting spring barley (Hordeum vulgare L.). Eur J Agron 6(3):275-293

International Nut and Dried Fruits (2012) Global statistical review 20062011. Available at http://wwwnutfruitorg/global-statistical-review_ 13608pdf Accessed 17 Nov 2014

Jakovljevic T, Gredecki-Postenjak M, Radojcic IR (2009) Stone pine seeds (Pinus pinea L.), forest reproductive material and food. Rad Hrvatski Šumarski Institut 44(1):29-36

Krannitz PG, Duralia TE (2004) Cone and seed production in Pinus ponderosa: a review. West N Am Naturalist 64(2):208-218

Lobell DB, Ortiz-Monasterio JI, Asner GP, Naylor RL, Falcon WP (2005) Combining field surveys, remote sensing and regression trees to understand yield variations in an irrigated wheat landscape. Agron J 97:241-249

Loewe MV (2016) Characterization of variability, growth and production of Stone pine (Pinus pinea L.) in Chile according to climate and some silvicultural practices. Doctoral Thesis, University of Córdoba, Spain. $332 \mathrm{p}$

Loewe MV, Delard C (2012) Un Nuevo cultivo para Chile, el pino piñonero (Pinus pinea L.). Instituto Forestal, Santiago, Chile, p 364

Loewe MV, Delard RC (2015) Stone pine (Pinus pinea L.), an interesting alternative for agroforestry in Chile. In Small-scale and community forestry and the changing nature of forest landscapes 11-15 October 2015. Sunshine Coast, Australia

Loewe MV, Delard RC, Balzarini M, Álvarez CA, Navarro-Cerrillo RM (2015) Impact of climate and management variables on stone pine (Pinus pinea L.) growing in Chile. Agric For Meteorol 214-215: $106-116$

Loewe MV, Balzarini M, Álvarez A, Delard C, Navarro-Cerrillo RM (2016) Fruit productivity of Stone pine (Pinus pinea L.) along a climatic gradient in Chile. Agric For Meteorol 223:203-216

Lonja de Reus (2018) Histórico de precios. http://www.llotjadereus.org. Accessed 1 April 2018

Mercau JL, Sadras VO, Satorre EH, Messina C, Balbi C, Uribelarrea M, Hall AJ (2001) On-farm assessment of regional and seasonal variation in sunflower yield in Argentina. Agric Syst 67(2):83-103

Montero G, Calama R, Ruiz-Peinado R (2008) Selvicoltura de Pinus pinea L. In: Montero G, Serrada R, Reque (ed.), Compendio de selvicoltura de especies. Madrid, Spain: INIA-Fundación Conde del Valle de Salazar, pp. 431-470

Mutke S, Gordo J, Gil L (2005) Variability of Mediterranean Stone pine cone production: yield loss as response to climate change. Agric For Meteorol 132(3-4):263-272

Mutke S, Gordo J, Gil L (2006) Perdida de producción de piña en los pinares de piñonero como consecuencia del cambio climático. Foresta 32:34-38 
Mutke S, Calama R, Gordo J, Alvarez D, Gil L (2007) Stone pine orchards for nuts production: which, where, how? Nucis Newslett 14 : $22-25$

Mutke S, Calama R, González-Martínez S (2012) Mediterranean Stone pine: botany and horticulture. Hortic Rev 39:153-201

Mutke S, Martínez J, Gordo J, Nicolas JL, Herrero N, Pastor A, Calama R (2014) Severe seed yield loss in Mediterranean Stone pine cones. 5th International Conference on Mediterranean Pines (Medpine5) September 22-26, 2014. Solsona, Spain: s.n.

Mutke S, Calama R, Montero G, Gordo J (2015a) Pine nut production from forests and agroforestry systems around the Mediterranean - a short overview. In European Non Wood Forest Products $3^{\text {rd }}$ Workshop 18-20 February 2015. Zagreb, Croatia

Mutke S, Calama R, Gordo J, Nicolas JL, Herrero N, Roques A (2015b) Pérdida del rendimiento en piñón blanco de Pinus pinea en fábricaLeptoglossus y la seca de la piña. III Reun Cien de San For, SECF. SECF. Madrid 7-8 October

Mutke S, Roque A, Calama R (2016) Impact of the dry cone syndrome on kernel yield from Stone pine cones. In: Mutke CS, Correia AC, Verde V (eds) AgroPine2016. 2nd International Meeting on Mediterranean Stone Pine for Agroforestry 2016/05/18-20. INIA, Oeiras, Portugal

Nunes A, Pereira H, Tomé M, Silva J, Fontes L (2016) Tomography as a method to study umbrella pine (Pinus pinea) cones and nuts. Forest Syst 25(2):1-5

Otegui ME, Nicolini MG, Ruiz RA, Dodds PA (1995) Sowing date effects on grain yield components for different maize genotypes. Agron J 87(1):29-33

Patterson HD, Thompson R (1971) Recovery of inter-block information when block sizes are unequal. Biometrika 58:545-554
Pearson K (1920) Notes on the history of correlation. Biometrika 13:2545

Peruzzi A, Cherubini P, Gorreri L, Cavalli S (1998) Le pinete e la produzione dei pinoli dal passato ai giorni nostri, nel territorio del parco di Migliarino, S. Rossore, Massaciuccoli. S.1.: Felici Editore

Phakamas N, Patanothai A, Jogloy S, Pannangpetch K, Hoogenboom G (2008) Physiological determinants for pod yield of peanut lines. Crop Sci 48(6):2351-2360

Silveira P. (2012) Pihna ou Pinhão negro, rentabilidade e resultados. Seminario "Valorizaçao da Fileira da Pihna/Pinhao". September 18, 2012. Alcácer do Sal, Portugal: s.n

Sousa E, Ferreira C, Pimpão M, Naves P, Valdiviesso T (2012) Sanidade dos povoamentos de pinheiro manso em Portugal. Seminario "Valorizaçao da Fileira da Pihna/Pinhao". September 18, 2012. Alcácer do Sal, Portugal

West B, Welch K, Galecki A (2014) Linear mixed models: a practical guide using statistical software. CRC Press, New York, p 440

Wetzstein HY, Zhang Z, Ravid N, Wetzstein ME (2011) Characterization of attributes related to fruit size in pomegranate. HortScience 46(6): 908-912

Wiegand CL, Cuellar JA (1981) Duration of grain filling and kernel weight of wheat as affected by temperature. Crop Sci 21(1):95-101

Zapata T, Silva C, Acevedo H (2004) Comportamiento de isolíneas de altura en relación con el rendimiento y distribución de asimilados en trigo. Agric Técnica 64(2):139-155

Publisher's note Springer Nature remains neutral with regard to jurisdictional claims in published maps and institutional affiliations. 